\title{
ORGANIC CARBON AND TOTAL NITROGEN IN THE DENSIMETRIC FRACTIONS OF ORGANIC MATTER UNDER DIFFERENT SOIL MANAGEMENT ${ }^{1}$
}

\author{
MARCELO RIBEIRO VILELA PRADO ${ }^{2}$, FABRICIO TOMAZ RAMOS ${ }^{2 *}$, OSCARLINA LÚCIA DOS SANTOS \\ WEBER $^{2}$, CAIO BATISTA MÜLLER ${ }^{2}$
}

\begin{abstract}
The evaluation of land use and management by the measurement of soil organic matter and its fractions has gained attention since it helps in the understanding of the dynamics of their contribution to soil productivity, especially in tropical environments. This study was conducted in the municipality of Colorado do Oeste, state of Rondônia, Brazil and its aim was to determinethe quantity of organic carbon and total nitrogen in the light and heavy fractions of organic matter in the surface layers of a typic hapludalf under different land use systems: Native Forest: open evergreen forest, reference environment; Agroforestry System 1: teak (Tectona grandis LF) and kudzu (Pueraria montana); Agroforestry System 2: coffee (Coffea canephora), marandu palisade grass (Brachiaria brizantha cv. Marandu), "pinho cuiabano" (Parkia multijuga), teak and kudzu.; Agroforestry System 3: teak and cocoa (Theobroma cacao); Silvopasture System: teak, cocoa and marandu palisade grass; and Extensive Grazing System: marandu palisade grass. The experimental design was a randomized block in split-split plots (use systems versus soil layers of 0-0.05 and 0.05-0.10 m) with three replications. The results showed that relative to Native Forest, the Agroforestry System 2 had equal- and greater amounts of organic carbon and total nitrogen respectively (light and heavy fractions) in the soil organic matter, with the light fraction being responsible for storage of approximately $45 \%$ and $70 \%$ of the organic carbon and total nitrogen, respectively. Therefore, the light densimetric fraction proved to be useful in the early identification of the general decline of the soil organic matter in the land use systems evaluated.
\end{abstract}

Keywords: Silvopasture system. Agroforestry system. Forest cultivation.

\section{CARBONO ORGÂNICO E NITROGÊNIO TOTAL NAS FRAÇÕES DENSIMÉTRICAS DA MATÉRIA ORGÂNICA SOB DIFERENTES MANEJOS DO SOLO}

\begin{abstract}
RESUMO - A avaliação de sistemas de uso e manejo dos solos por meio da matéria orgânica e seus compartimentos tem ganhado apelo, pois ajuda a entender a dinâmica do seu aporte, principalmente em ambientes tropicais. Objetivou-se neste trabalho determinar, no município de Colorado do Oeste, Rondônia, a alteração do carbono orgânico e nitrogênio total nas frações leve e pesada da matéria orgânica da camada superficial de um ARGISSOLO VERMELHO-AMARELO Eutrófico típico sob diferentes usos do solo: Floresta nativa (FN): Floresta Ombrófila Aberta, como ambiente referência; sistema agroflorestal 1: teca (Tectona grandis L. F.) e kudzu (Pueraria montana); sistema agroflorestal 2: café (Coffea canephora), pastagem (Brachiaria brizantha cv. Marandu), pinho cuiabano (Parkia multijuca), teca e kudzu; Sistema agrossilvopastoril: Teca, cacau (Theobroma cacao) e pastagem; sistema agroflorestal 3: Teca e cacau; pastagem extensiva: (B. brizantha cv. Marandu). O delineamento empregado foi o de blocos casualizados em esquema de parcelas subdivididas (diferentes coberturas vegetais versus camadas de solo à $0-0,05$ e a 0,05-0,10 m) com três repetições. Verificou-se que: comparado a floresta nativa houve aumento e igualdade na quantidade de carbono orgânico e nitrogênio total da fração leve e pesada da matéria orgânica do solo no "sistema agroflorestal 2"; a fração leve foi responsável pelo armazenamento de aproximadamente $45 \%$ e $70 \%$ do carbono orgânico e nitrogênio total do solo, respectivamente. Portanto, o diagnóstico da fração densimétrica leve é o mais indicado para identificação precoce do declínio geral da matéria orgânica do solo.
\end{abstract}

Palavras-chave: Sistema agrosilvopastoril. Sistema agroflorestal. Cultivo florestal.

\footnotetext{
*Corresponding author

${ }^{1}$ Received for publication in $07 / 03 / 2014$; accepted in $01 / 25 / 2016$.

Paper extracted from the doctoral thesis of the fourth author.

${ }^{2}$ Postgraduate Program in Tropical Agriculture, Universidade Federal de Mato Grosso, Cuiabá, MT, Brazil; vilelamarcelo@yahoo.com.br, fabriciotomazramos@gmail.com,oscarlinaweber@gmail.com, caiomuller@hotmail.com.
} 


\section{INTRODUCTION}

Deforestation in the Amazon region has been closely associated with the expansion of the agricultural frontier since the 1970s. Most of the cleared areas are now occupied by pastures being grazed extensively by a small number of animals per hectare. This is a recurring problem in other regions of Brazil and it demands changes in public policies that would help to increase both the resilience and the profitability of agricultural systems, which in turn would ease the pressure to clear new areas (MMA, 2013). Deforestation causes the loss of biodiversity in flora and fauna and also decreases the sequestration of $\mathrm{C}-\mathrm{CO}_{2}(\mathrm{~g})$, thereby aggravating the greenhouse effect (WHITE, 2006). One alternative recommended to reduce deforestation is the use of "agroforestry systems", which combine crops, orchards, extractive forests and/or grazing land as a way to make better economic use of the land (SANTOS et al., 2000); and increase soil fertility by increasing soil organic matter (SOM) (FÁVERO et al., 2008; IWATA et al., 2012).

A dependence relationship exists between SOM and various chemical, physical and biological processes in terrestrial ecosystems (STRICKLAND; ROUSK, 2010). Several authors have stressed the importance of organic matter in determining soil quality because it influences, among other properties, the stability of the aggregates and the structure of the soil (HICKMANN et al., 2012; RAMOS et al., 2013); the rate of water infiltration and retention (RAWLS et al., 2003); biological activity and cation exchange capacity (SILVA; MENDONÇA, 2007); the complexation of metals (BEZERRA et al., 2009); the cycling and availability of nutrients to plants (SILVA et al., 2009); and the release of $\mathrm{CO}_{2}$ and other gases (LAL; BRUCE, 1999).

The fractions of the SOM can be characterized by physical and/or chemical methods, depending on the purpose of the investigation. Physical methods involve separation of the constituents according to their relative densities (called densimetry), while chemical methods are based on the diameters of the particles or aggregates in the soil (ROSCOE; MACHADO, 2002; MARTINS et al., 2009). There are basically two fractions: the first is particulate SOM (light-density fraction), either free or occluded, depending upon whether it is located within or between the soil aggregate. It is an important source of labile nutrients to plants due to its rapid mineralization rate (GOLCHIN et al., 1994). The heavy-density fraction is the SOM associated with the mineral particles in the soil, forming organ mineral complexes. It is composed of organic residues with high specific densities and rates of decomposition. These are important factorsin the sequestration of $\mathrm{C}-\mathrm{CO}_{2}(\mathrm{~g})$ (WHITE, 2006; ROSCOE et al., 2006).

In view of this background, the aim of this study was to determine the variations in organic carbon and total nitrogen of the light and heavy fractions of the surface organic matter of an ARGISSOLO VERMELHO-AMARELO Eutrófico tipico (TYPIC HAPLUDALF) under different use systems: native forest, three agroforestry systems, a silvopasture system and extensive cattle grazing.

\section{MATERIALS AND METHODS}

\section{Study site}

The study was carried out at the Estrela farm, located $9.5 \mathrm{~km}$ from the Escondido River in the municipality of Colorado do Oeste, in the southern region of the state of Rondônia, at the geographic coordinates $13^{\circ} 09^{\prime} 29,4^{\prime \prime} \mathrm{S}$ and $60^{\circ} 37^{\prime} 50,6^{\prime}$ ' W, at an altitude of 333 meters. The region's climate is "Am" according to the Köppen classification tropical hot and humid with an average annual temperature of 24 ${ }^{\circ} \mathrm{C}$ (minimum $12{ }^{\circ} \mathrm{C}$ and maximum $36{ }^{\circ} \mathrm{C}$ ) and thermal amplitude of $10{ }^{\circ} \mathrm{C}$. The average yearly rainfall is 2,234 mm, with January to March being the wettest months. The soil in the study area is classified as an ARGISSOLO VERMELHOAMARELO Eutrófico típico (or TYPIC HAPLUDALF), moderate horizon “A," medium/clay texture, and the terrain is gently rolling (SANTOS et al., 2013).

\section{Experimental design}

The experimental design was a randomized block in split-split plots (use systems versus soil layers of $0-0.05$ and $0.05-0.10 \mathrm{~m}$ ), with three replications. The experimental unit consisted of six adjacent land plots under different use systems (described in Table 1). 
Table 1. Land use history of the experimental plots in Colorado do Oeste, State of Rondônia, Brazil.

\begin{tabular}{l}
\hline \multicolumn{1}{c}{ Plant cover/use } \\
\hline $\begin{array}{l}\text { Natural Forest (open } \\
\text { evergreen forest) }\end{array}$ \\
\\
Agroforestry System 1 \\
Teak and kudzu
\end{tabular}
Teak and kudzu.

Agroforestry System 2: Coffee, mandaru palisade grass, pinho cuiabano, teak and kudzu.

Silvipastoril System: Teak, cacao, and mandaru palisade grass.

Agroforestry System 3: Teak and cacao.

Extensive Grazing: Mandaru palisade grass

History

-Area covered by "open tropical forest" (semideciduous, submontane, emerging dossel), with 20 to $50 \%$ of the leaves remaining during the dry season.

-Teak (Tectona grandis L. F.) planted without fertilization of the soil in December 2001, cultivated in an area of 7.0 ha with spacing of $3 \times 2 \mathrm{~m}$, after manual removal of the primary forest in 1998 followed by burning. In the first two years (1999 and 2000), rice, corn, and beans were grown in combination in alternating rows, without soil correction or fertilization. In February 2000, the soil was seeded with kudzu (Pueraria montana), which remained until 2007, the year of the sampling.

- Teak planted in 1998, where the primary forest had been removed in June 1975 followed by burning, after which coffee (Coffea canephora) was planted, along with rice, corn and beans in alternating rows between the rows of coffee and grown for four years without fertilization. In the fifth year, grass was introduced (Brachiaria brizantha cv. Marandu), and in 1984 pinho cuiabano (Parkia multijuga) was AFS 2 planted, in an area of 10 hectares with spacing of $3 \times 5 \mathrm{~m}$. Some seedlings died, however, so teak was planted as a replacement. The pasture was managed with rotating grazing of cattle $\left(2\right.$ animals ha $\left.{ }^{-1}\right)$ and in the dry season, when the grass had low renewal capacity, the animals were transferred to the "extensive grazing" area. In December 2000, kudzu was planted to replace pasture, and remained until 2007 , the year of the sampling.

- Teak planted without fertilization of the soil in December 1998, cultivated in an area of 5.0 ha with spacing of $3 \times 2 \mathrm{~m}$ where the primary forest had been manually removed in 1998, followed by burning. In December 2000, cacao (Theobroma cacao) was planted between the rows of trees, along with grass (B. brizantha). The pasture management was the same as AFS 2, and grazing continued until 2007, the year of the sampling.

- Teak planted without fertilization of the soil in December 1998, cultivated in an area of 5.0 ha with spacing of $3 \times 2 \mathrm{~m}$ where the primary forest had been manually removed in 1998, followed by burning. In December 2000, cacao was planted between the rows of trees, and remained until 2007, the year of the sampling.

- An area covering approximately 10 hectares cleared in 2001 by manual removal of the forest followed by burning and seeding of grass (B. brizantha) without application of fertilizer and soil correction. After the establishment of the pasture, cattle were extensively grazed (under 2 animals per hectare), resulting in an uneven pattern of grass cover, with some areas undergrazed and others overgrazed. The grazing system was maintained until 2007, the year of the sampling.

In each treatment, an area covering approximately $2,500 \mathrm{~m}^{2}(50 \times 50 \mathrm{~m})$ was demarcated to sample the soil in a random zigzag pattern, with a strip 10 meters wide between each plot. At each sampling point, monolithic soil samples were collected in two layers ( 0 to 0.05 and 0.05 to $0.10 \mathrm{~m}$ ). Three small trenches were opened in the form of steps. The soil samples were immediately placed in hermetically sealed rigid plastic containers to preserve the initial moisture and structure during transport to the soil physics laboratory of the Federal University of Mato Grosso in Cuiabá, Brazil.

\section{Laboratory analysis}

In the laboratory, the monoliths were further moistened by applying distilled water with a sprinkler to attain a friable consistency and to break the soil structure on the weak surfaces, as described by Salton et al. (2012). The samples were then airdried and the aggregates were separated into two parts (particles smaller than $2 \mathrm{~mm}$, and particles bigger than $2 \mathrm{~mm}$ ) by sifting through a sieve with 2 $\mathrm{mm}$ mesh attached to an electromagnetic shaker
(Endecotts Limited, Octagon Digital D200, London, England), adjusted to the median vibration setting of "5", for one minute. The root material was then removed and the samples were stored in plastic trays.

Preliminary tests showed that in order to obtain sufficient quantities of low-density organic matter, namely, the light fraction (LF; described above) for the carbon and nitrogen analyses, it was necessary to use $30 \mathrm{~g}$ of soil from the surface layer $(0$ to $0.05 \mathrm{~m})$ and $60 \mathrm{~g}$ from the subsurface layer $(0.05$ to $0.10 \mathrm{~m})$. The quantities of aggregates used that were larger than or equal to $2 \mathrm{~mm}$ (LA $\geq 2 \mathrm{~mm})+$ smaller than $2 \mathrm{~mm}$ (SA $<2 \mathrm{~mm}$ ) were calculated based on the average result of the dry sifting of the samples collected from each land use area, in the proportion of $60 \%$ LA to $40 \%$ SA.

For each class of aggregates, the light and heavy fractions of the SOM were separated by flotation in a solution of NaI at a density of $1.7 \mathrm{~g} \mathrm{~L}^{-1}$ (densimetric method), adapted from Roscoe and Machado (2002), as depicted in Figure 1. The pH of the $\mathrm{NaI}$ was adjusted to 4.0 with a solution of 1.0 mol L $\mathrm{L}^{-1} \mathrm{HCl}$ so that the organic matter would not dissolve.

Two amounts of soil (30 g and $60 \mathrm{~g}$ ) were 
weighed out from the surface and subsurface layer. These samples were placed in $500 \mathrm{~mL}$ glass beakers (VAT no. 42) containing 50 and $100 \mathrm{~mL}$ of the $\mathrm{NaI}$ solution respectively. The beakers were then placed in a horizontal agitator (Tecnal, TE-167, Piracicaba, $\mathrm{SP}$, Brazil) for $14 \mathrm{~h}$ at $40 \mathrm{rpm}$, providing sufficient time to break up the soil clumps.

The light fraction (LF) was skimmed off the top after flotation then filtered through qualitative filter paper and set aside, while the filtrate $(\mathrm{NaI})$ was returned to the beaker and stirred with a glass rod to decompose the pellet for recovery of the LF. This was followed by recentrifuging and filtration to separate the LF. This process was repeated two or three times until no more flocculated LF remained after spinning. The recovered LF was filtered again and washed with $400 \mathrm{~mL}$ distilled water and $100 \mathrm{~mL}$ of $0.01 \mathrm{~mol} \mathrm{~L}^{-1} \mathrm{CaCl}_{2}$ to remove the NaI. The LF was then dried in a circulating-air chamber for 24 at 50 ${ }^{\circ} \mathrm{C}$ then weighed, macerated and set aside for the determination of the quantities of organic carbon and total nitrogen.

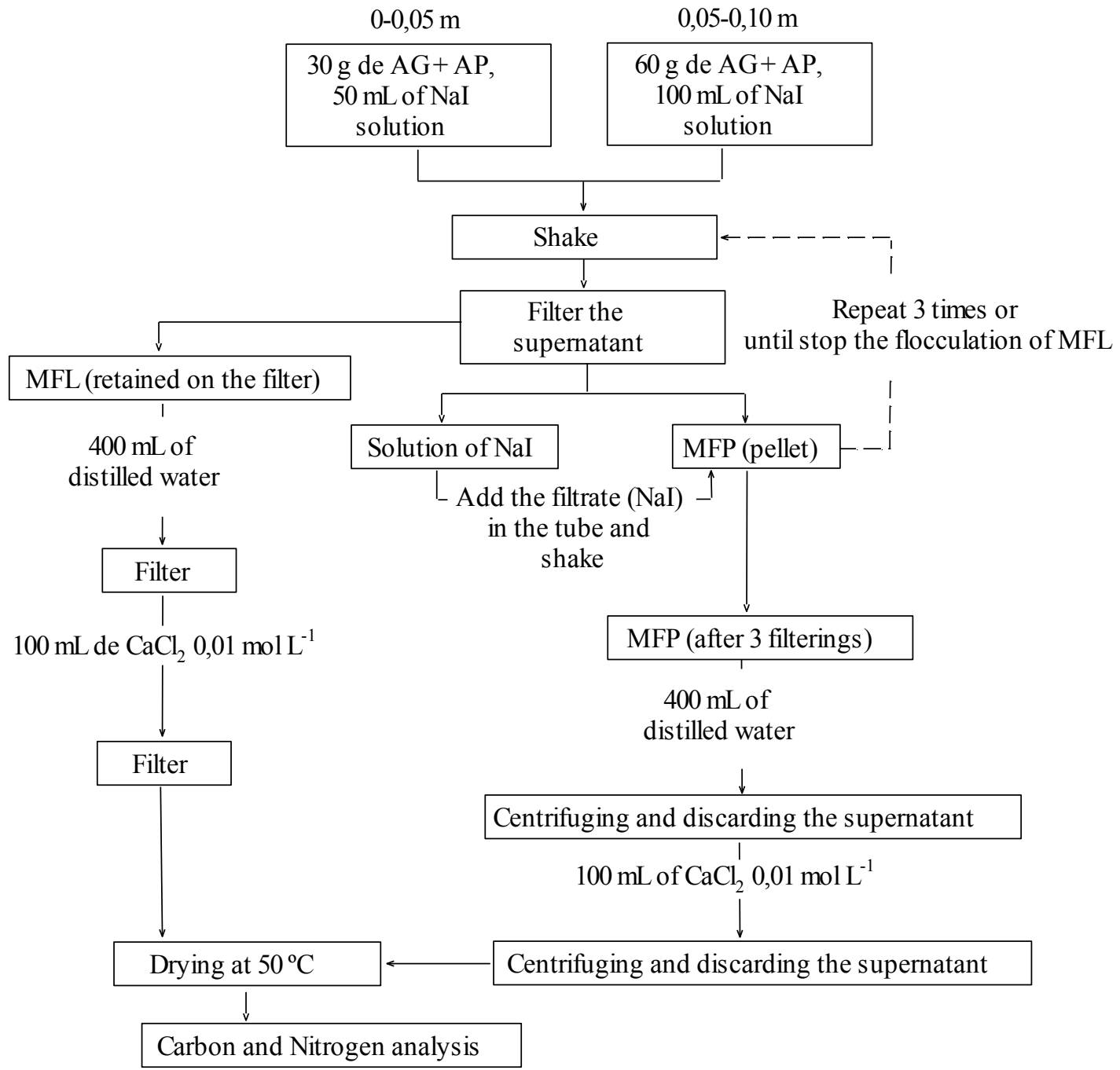

Figure 1. Flowchart showing the process of separating the light and heavy organic matter fractions. Remark: LA and SA = aggregates equal to or larger than $2 \mathrm{~mm}(\mathrm{LA} \geq 2 \mathrm{~mm})$ and smaller than $2 \mathrm{~mm}(\mathrm{SA}<2 \mathrm{~mm})$ respectively; $\mathrm{LF}$ and $\mathrm{HF}=$ light and heavy fractions of soil organic matter respectively.

To remove the NaI from the HF, the material was washed five times with $80 \mathrm{~mL}$ distilled water and once with $100 \mathrm{~mL}$ of $0.01 \mathrm{~mol} \mathrm{~L}^{-1} \mathrm{CaCl}_{2}$. With each washing, the pellet was homogenized with a glass rod to release the $\mathrm{NaI}$ adhering to the particles. After the $\mathrm{CaCl}_{2}$ washing, the $\mathrm{HF}$ was dried in a circulating-air chamber at $50{ }^{\circ} \mathrm{C}$ for $48 \mathrm{~h}$, macerated and set aside for the analysis of the organic carbon and total nitrogen (Figure 1).

The organic carbon (OC) content of the light and heavy fractions was quantified by moist combustion in a solution of potassium dichromate in an acid medium $\left(\mathrm{H}_{2} \mathrm{SO}_{4}\right)$ with heating in a block digester. The excess potassium dichromate was titrated with ammonium iron (II) sulfate using "ferroin" as the indicator (YEOMANS; BREMNER, 1988). In this method, it is the recommended to use 100 to $500 \mathrm{mg}$ of the soil sample, because the quantity of organic carbon in the sample should not exceed $8.0 \mathrm{mg}$. For the LF, which contains a larger 
quantity of organic matter, we used $20 \mathrm{mg}$. The results were expressed in $\mathrm{g} \mathrm{kg}^{-1}$. The total nitrogen (TN) of the light and heavy fractions was measured by the Kjeldahl method, as described in Tedesco (1995). For both fractions, $500 \mathrm{mg}$ were used and the results were expressed in $\mathrm{g} \mathrm{kg}^{-1}$.

\section{Statistics analysis}

According to the Shapiro-Wilk test $(\mathrm{p}>0.05)$, the data obtained were not normally distributed, so an analysis of variance was run using SigmaPlot ${ }^{\circledR}$ version 12.5 applying the F-test (Fischer), and the means of the samples from the different land use areas were compared by the Tukey test $(\mathrm{p}<0.05)$ according to Larson and Farber (2010).

\section{RESULTS AND DISCUSSION}

\section{Organic carbon and total nitrogen in the light and heavy fractions}

With respect to the proportions of light and heavy fractions in the initial $30 \mathrm{~g}$ soil sample, the mass of LF in the samples drawn from the different land use areas varied from 3.75 to $6.96 \mathrm{~g}$ in the 0 $0.05 \mathrm{~m}$ layer and 2.03 to $5.91 \mathrm{~g}$ in the $0.05-0.10 \mathrm{~m}$ layer (Figure 2).

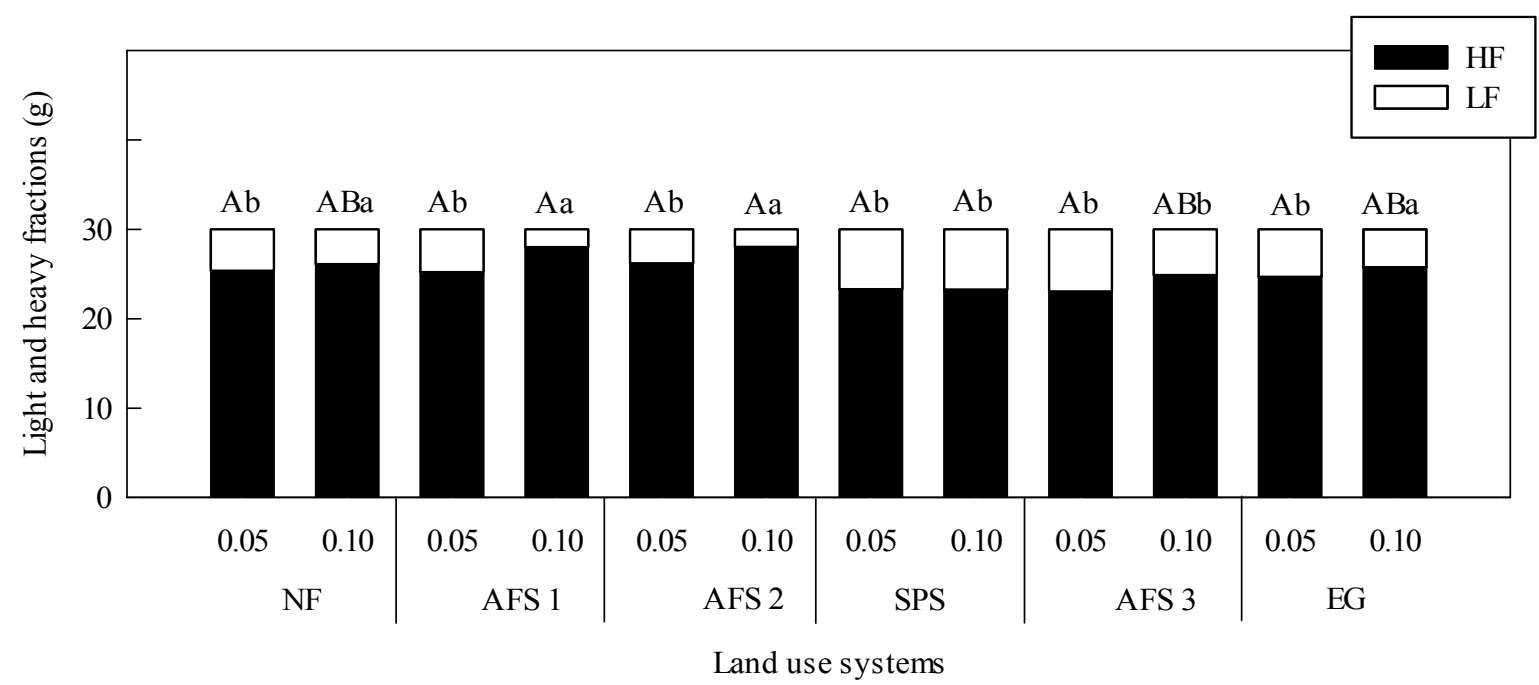

Figure 2. Mass of light fractions (LF) and heavy fractions (HF) (g) in each land use system and soil layer sampled. Remark: Native Forest (NF): open evergreen forest, as a reference environment; Agroforestry System 1 (AFS 1): teak (Tectona grandis LF) and kudzu (Pueraria montana); Agroforestry System 2 (AFS 2): coffee (Coffea canephora), marandu palisade grass (Brachiaria brizantha cv. Marandu), pinho cuiabano (Parkia multijuca), teak and kudzu; Agroforestry System 3 (AFS 3): teak and cocoa (Theobroma cacao); Silvopasture System (SPS): teak, cocoa and marandu palisade grass; and Extensive Grazing (EG) [System]: marandu palisade grass. Capital letters compare the layers (m) in the same system while small letters compare the systems in the same soil layer, by the Tukey test $(\mathrm{P}<0.05)$.

The average concentrations of organic carbon (OC) and total nitrogen (TN) in the light and heavy fractions of organic matter are presented in Figure 3. It can be seen that for the light fraction in the surface layer, the samples from the AFS 1, AFS 2 and SPS areas contained the highest amounts of OC, while in the subsurface layer, AFS 1 and AFS 2 were the standouts (Figure 3A). For the heavy fraction, AFS 2 and $E G$ in the surface layer and in the subsurface layer can be considered the best soil management systems because they had levels of CO closer to that of native forest (NF) (Figure 3B) than did the others. Based on this observation and the quantities of $\mathrm{OC}$, only the AFS 1 and AFS 2 systems did not differ in the average $\mathrm{OC}$ values of the light fraction, regardless of the layer, and in both cases they were greater than that of the native forest (NF) (Figure $3 \mathrm{~A})$. With respect to the heavy fraction, AFS 2 also did not differ in OC content between the two layers, but was equal in terms of $\mathrm{OC}$ to the NF area in the surface layer and to the EG area in the subsurface layer (Figure 3B).

In relation to the $\mathrm{TN}$, when contrasting the systems at the level of the same layer, the highest TN levels in the light fraction were found in the surface layer of the AFS 1 area, and in the subsurface layers of the NF and AFS 2 areas (Figure 3C). For the heavy fraction, the AFS 3 and EG areas retained the highest TN levels, in both layers (Figure 3D). 

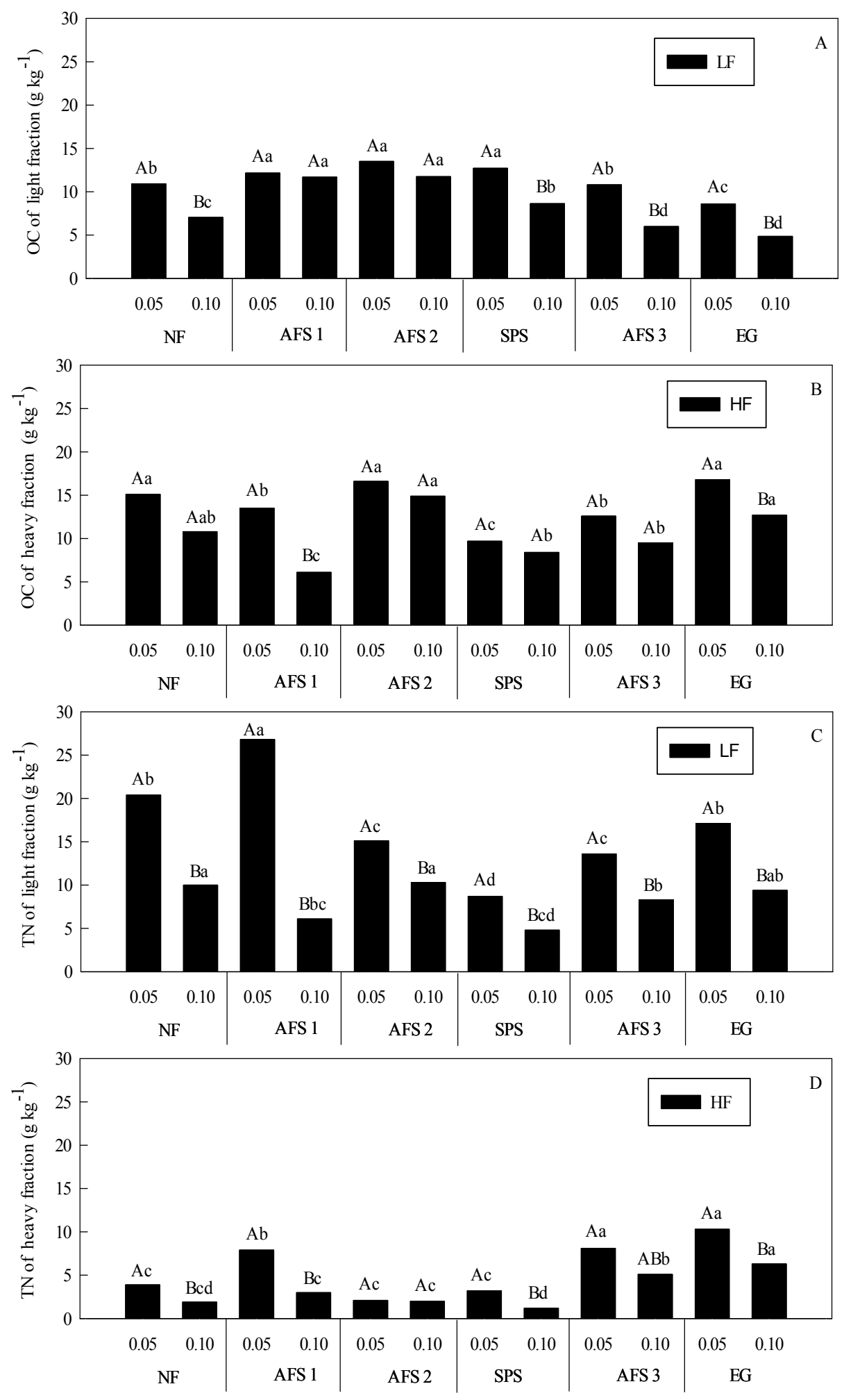

Land use systems

Figure 3. Organic carbon (OC) and total nitrogen (TN), in the light and heavy fractions under different land use systems: Native Forest (NF): open evergreen forest, as a reference environment; Agroforestry System 1 (AFS 1): teak (Tectona grandis LF) and kudzu (Pueraria montana); Agroforestry System 2 (AFS 2): coffee (Coffea canephora), marandu palisade grass (Brachiaria brizantha cv. Marandu), pinho cuiabano (Parkia multijuca), teak and kudzu; Agroforestry System 3 (AFS 3): teak and cocoa (Theobroma cacao); Silvopasture System (SPS): teak, cocoa and marandu palisade grass; and Extensive Grazing (EG) [System]: marandu palisade grass. Capital letters compare the layers in the same system while small letters compare the systems in the same soil layer, by the Tukey test $(\mathrm{P}<0.05)$. 
The average values of organic carbon (OC) found in the light fraction varied from 4.7 to $13.5 \mathrm{~g}$ $\mathrm{kg}^{-1}$ (Figure 3A) and from 4.8 to $26.8 \mathrm{~g} \mathrm{~kg}^{-1}$ for total nitrogen (TN) (Figure 3C). In the heavy fraction, the range was 6.1 to $16.8 \mathrm{~g} \mathrm{~kg}^{-1}$ (Figure 3B) for $\mathrm{OC}$ and 1.2 to $10.3 \mathrm{~g} \mathrm{~kg}^{-1}$ for TN (Figure 3D). An interesting observation is that although the light fraction had a lower proportion of the total mass than did the heavy fraction (Figure 2), based on the data of Figure 3, it accounted for approximately $45 \%(0-0.05 \mathrm{~m})$ and $44 \%(0.05-0.10 \mathrm{~m})$ of the OC, and $74 \%(0-0.05 \mathrm{~m})$ and $71 \%(0.05-0.10 \mathrm{~m})$ of the $\mathrm{TN}$, when considering the averages of the values under the land use systems for each layer evaluated. These results are similar to those reported by Freixo et al. (2002). It appears, therefore, that the light fraction alone is able to store a large part of the OC and TN.

According to Roscoe and Machado (2002) and Silva et al. (2009), the light fraction is an important source of labile nutrients for plants due to the relatively faster decomposition, mineralization and nutrient cycling in this zone. The measurement of these nutrients is therefore very useful for planning techniques that will reduce the decomposition of these nutrients and, over time, maintain or increase the quality and quantity of organic matter.

Regardless of the soil layer, the light fractions of the AFS 1 and AFS 2 use systems did not differ in terms of average OC values, and their average OC levels were greater than those of the native forest (NF) (Figure 3A). With respect to the OC content of the heavy fraction, however, only the AFS 2 soil did not differ between the two layers. The NF, AFS 1 and EG systems were equal to the AFS 2 in this respect, but only in the subsurface soil layer (Figure $3 \mathrm{~B})$. It can thus be deduced that the longer cultivation time and greater heterogeneity of cultures in the agroforestry system AFS 2 (Table 1) favored a greater equilibrium with time between the $\mathrm{OC}$ of the light (Figure 3A) and heavy fraction (Figure 3B) than did the less diverse land use.

In general, the surface layer stored more nitrogen than did the subsurface layer, probably because, according to White (2006), microorganisms and organic residues are more plentiful in the surface layer than they are in the lower strata. Furthermore, up to $95 \%$ of the nitrogen in the soil is found in organic form (RANGEL; SILVA, 2007).

In light of these findings, the quantity of carbon in the soil can be maintained or even increased to higher quantities than in native environments with the use of more varied production systems wherein different plants and animals are combined as is the case of AFS 2 (Table 1) (ARAÚJO et al., 2011). This argument is justified because, as reported by Rangel and Silva (2007), Iwata et al. (2012) and Magalhães et al. (2013), systems that favor the constant production of plant or animal biomass increase the content of carbon and various nutrients in the soil including nitrogen.

The cultivation of pasture caused $\mathrm{OC}$ to accumulate in the heavy fraction of the surface layers in the AFS 2, EG and NF areas (Figure 3B). $\mathrm{TN}$ levels were equal in the light fractions of both the EG and NF systems (Figure 3C) whereas TN was greater in the heavy fraction of EG than it was in NF (Figure 3D). According to D'Andrea et al. (2004) and Rossi et al. (2012), productive systems that include grasses such as Brachiaria sp. are efficient in storing carbon mainly because grasses have an abundant and voluminous branched root system with continuous renovation, entrance and cycling.

According to Fávero et al. (2008), although the total organic carbon content of soil under pasture can be higher [than it is in other land use systems], in soil under agroforestry systems the less stable organic fractions (light fractions) are more dynamic than they are elsewhere which, according to Iwata et al. (2012), increases the availability of nutrients to plants. According to Redin et al. (2011), the burning of organic wastes accelerates their mineralization and causes the loss of $\mathrm{C}$ via the release of $\mathrm{CO}_{2}$. It is therefore natural that plants initially develop vigorously but this effect wanes due to the loss of $\mathrm{C}-\mathrm{CO}_{2}$ through microbial respiration, soil erosion and the leaching of nutrients from the ashes. This phenomenon especially holds true in the case of monocultures, which, according to Ramos et al. (2010), can cause an imbalance in the soil's microbiota. Therefore, it is likely that burning catalyzed the decomposition of the light fraction of the SOM, thereby increasing the quantity of the heavy fraction. Since the EG area is an inadequately maintained monoculture however, it was already showing signs of degradation during the study period (Table 1). According to Giacomini et al. (2003), plant nitrogen supply and demand should be synchronized. In other words, even after native forests are clear-cut, the use of polycultures (such as agroforestry systems) can raise OC and TN levels (Figure 3).

The results also indicated that not only is it important to know the general concentrations of OC and $\mathrm{TN}$, but it is also necessary to know their proportions of light and heavy fractions (Figure 3). Since the accumulation of the heavy fraction depends on the input of the light fraction, and therefore the activity of soil organisms, the carbon/ nitrogen ratio $(\mathrm{C} / \mathrm{N})$ can be used to make inferences about soil quality (SILVA; MENDONÇA, 2007). The rate of degradation of organic residues in each type of land use system strongly influences the cycling of nutrients such as nitrogen and hence, by extension, their availability to plants (GIACOMINI et al., 2003; WHITE, 2006).

Ratio of carbon to total nitrogen in the light and heavy fractions 
It is known that in order for nutrients such as nitrogen derived from organic wastes to become available (mineralized) to plants, the organic matter must first need to be decomposed by soil microorganisms. Each microorganism, however, has its own ideal demand for chemical elements such as $\mathrm{C}$ and $\mathrm{N}$ (WHITE, 2006). Soil microorganisms use N as an energy source and $\mathrm{C}$ to form cells and tissues. Assuming that the $\mathrm{C} / \mathrm{N}$ ratio of fungi and bacteria is $8: 1$, as proposed by White (2006), when the waste matter has a $\mathrm{C} / \mathrm{N}$ ratio of about $24: 1$, there is an equilibrium between the absorption and the release of $\mathrm{N}$ (immobilization). When the waste has a $\mathrm{C} / \mathrm{N}$ ratio of around 90:1, nitrogen is taken up by the soil (deficit). When the waste has a $\mathrm{C} / \mathrm{N}$ ratio of about $9: 1$, nitrogen is released from the soil (mineralization). Therefore, the higher the $\mathrm{C} / \mathrm{N}$ ratio, the lower the rates of decomposition, mineralization and the availability of $\mathrm{N}$ to plants.

In view of the above information, the land use areas with highest $\mathrm{C} / \mathrm{N}$ ratios (Figure 4) were the light fractions of the surface layer of the SPS and the subsurface layers of the AFS 2 and the SPS. For the heavy fractions the highest values were found in the surface layer of the AFS 1 area and the subsurface layers of the NF, AFS 1 and AFS 2 areas.

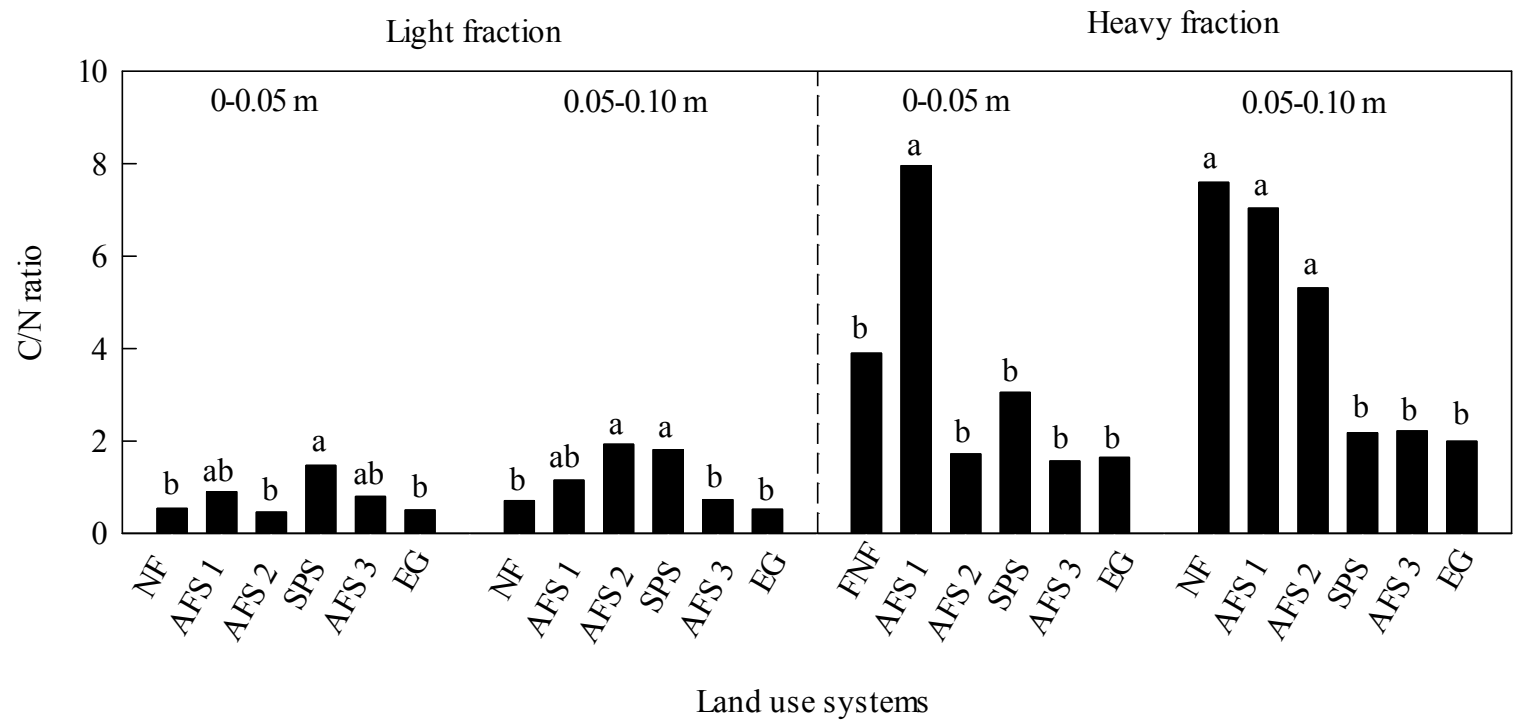

Figure 4. Ratio of carbon to total nitrogen $(\mathrm{C} / \mathrm{N})$ in the light and heavy fractions under different land use systems: Native Forest (NF): open evergreen forest, as a reference environment; Agroforestry System 1 (AFS 1): teak (Tectona grandis LF) and kudzu (Pueraria montana); Agroforestry System 2 (AFS 2): coffee (Coffea canephora), marandu palisade grass (Brachiaria brizantha cv. Marandu), pinho cuiabano (Parkia multijuca), teak and kudzu; Agroforestry System 3 (AFS 3): teak and cocoa (Theobroma cacao); Silvopasture System (SPS): teak, cocoa and marandu palisade grass; and Extensive Grazing (EG) [System]: marandu palisade grass. Capital letters compare the layers $(\mathrm{m})$ in the same system while small letters compare the systems in the same soil layer, by the Tukey test $(\mathrm{P}<0.05)$.

Arboreal species produce leaves, branches and stems with higher $\mathrm{C} / \mathrm{N}$ ratios than those found in grasses, which in turn have higher $\mathrm{C} / \mathrm{N}$ ratios than those of leguminous plants. Therefore, waste matter from arboreal species decomposes more slowly than that derived from other plant species (MOREIRA; COSTA, 2004). This tendency explains the observation in this study that the systems which accumulated the most $\mathrm{OC}$ and/or TN in the light and heavy densimetric fractions of the soil were not necessarily those with the highest $\mathrm{C} / \mathrm{N}$ ratios (Figure 4).

$\mathrm{C} / \mathrm{N}$ ratios were higher in the surface layers and lower in the subsurface layers for all land use systems except the SPS regarding in terms of its $\mathrm{C} / \mathrm{N}$ ratio in the light fraction and AFS 1 in the heavy fraction. Therefore the $\mathrm{C} / \mathrm{N}$ ratios differed depending upon the land use system and the soil layer evaluated probably due to the time- sensitive changes in the quality and quantity of organic matter entering them
(Table 1).

These results may be useful in the process of planning land uses and techniques that could reduce the mineralization of organic waste. The application of such strategies is particularly important for sandy soils because their higher oxygenation rates and their lower surface areas and load densities may impair the formation of organomineral complexes and make them more susceptible to leaching due to faster mineralization of organic wastes (ROSCOE; MACHADO, 2002; WHITE, 2006).

Therefore, if it is true that the higher the $\mathrm{C} / \mathrm{N}$ ratio, the slower the decomposition, mineralization and availability of $\mathrm{N}$ to plants, then all of the land use systems in this study would release nitrogen from the soil at a $\mathrm{C} / \mathrm{N}$ ratio of 9:1 (Figure 4), as described in White (2006). Nevertheless, the light fraction had a lower $\mathrm{C} / \mathrm{N}$ ratio than did the heavy fraction in all of the land use systems evaluated. A similar finding was also reported by Roscoe and 
Machado (2002), and by Silva and Mendonça (2007).

According to White (2006), the decomposition rate is determined not only by the $\mathrm{C} /$ $\mathrm{N}$ ratio but also by other characteristics of the plant in question such as its chemical composition, size, distribution, shoot and root branching, as well as the soil texture and temporal variations in gas and water content of gases and water with time, etc. and the atmosphere (evapotranspiration rates for each type of plant cover, etc.). For example, in the EG land use area, the $\mathrm{C} / \mathrm{N}$ ratio was statistically low in both the light and heavy fractions in comparison to the other systems.

According to Martins et al. (2009), soils in pasture areas have less recalcitrant organic matter than do those containing organic matter derived from the stalks and branches of arboreal species because the latter has a greater content of lignin, which is a chemical precursor of recalcitrant humic substances. According to Giacomini et al. (2003), agricultural systems consisting of a combination of species should produce dry matter with a $\mathrm{C} / \mathrm{N}$ ratio intermediate between that of each species alone in order to produce a longer-lasting soil cover with a greater synchrony between plant nitrogen supply and demand.

According to Texeira et al. (2009), in tropical areas, where weathering processes are strong and soils are highly susceptible to land management and use practices, it is important to maintain sufficient organic matter on the ground in all production systems, be they agricultural, forestry or agroforestry. Soil conservation practices can favor this maintenance system by occluding organic matter within soil aggregates or micropores (ROSCOE; BUURMAN, 2003). Furthermore, the protection of the organic matter depends upon the quality of the waste as well as its quantity. Since the nature of the organic matter varies with plant species, different humification routes must be activated via the interdependent activities of various soil micro, meso and macroorganisms (SILVA; MENDONÇA, 2007).

\section{CONCLUSIONS}

In comparison with the native forest, there were increases in both organic carbon and total nitrogen in the light and heavy fractions of the soil organic matter in the "Agroforestry System 2" area. This land use system was the most diverse of all of those studied. This finding indicates that a more diversified agroforestry management system is preferable to improve effectively soil quality over time after deforestation. Although the heavy organic matter fraction constituted over $90 \%$ by mass of the soil samples, the light fraction was responsible for storing approximately $45 \%$ and $70 \%$ of the organic carbon and total nitrogen in the soil respectively.
Therefore, it is important to know not only the general levels of organic carbon and total nitrogen but also their relative presence abundance in the light and heavy fractions. Finally, measurement of the light densimetric faction is indicated for the early identification of the general decline of organic matter in the soil.

\section{REFERENCES}

ARAÚJO, E. A. et al. Impacto da conversão florestapastagem nos estoques e na dinâmica do carbono e substâncias húmicas do solo no bioma Amazônico. Acta Amazônica, Manaus, v. 41, n. 1, p. 103-114, 2011.

BEZERRA, P. S. S.; TAKIYAMA, L. R.; BEZERRA, C. W. B. Complexação de íons de metais por matéria orgânica dissolvida: modelagem e aplicação em sistemas reais. Acta Amazônica, Manaus, v. 39, n. 3, p. 639-648, 2009.

D'ANDRÉA, A. F. et al. Estoque de carbono e nitrogênio e formas de nitrogênio mineral em um solo submetido a diferentes sistemas de manejo. Pesquisa Agropecuária Brasileira, Brasília, v. 39, n. 2, p. 179-186, 2004.

FÁVERO, C.; LOVO, I. C.; MENDONÇA, E. DE SÁ. Recuperação de área degradada com sistema agroflorestal no vale do Rio Doce, Minas Gerais. Revista Árvore, Viçosa, v. 32, n. 5, p. 861-868, 2008 .

FREIXO, A. A. et al. Estoques de carbono e nitrogênio e distribuição de frações orgânicas de Latossolo do Cerrado sob diferentes sistemas de cultivo. Revista Brasileira de Ciência do Solo, Viçosa, v. 26, n. 2, p. 425-434, 2002.

GIACOMINI, S. J. et al. Matéria seca, relação C/N e acúmulo de nitrogênio, fósforo e potássio em misturas de plantas de cobertura de solo. Revista Brasileira de Ciência do Solo, Viçosa, v. 27, n. 2, p. 325-334, 2003.

GOLCHIN, A. et al. Study of free and occluded particulate organic matter in soils by solid state $13 \mathrm{C}$ CP/MAS NMR spectroscopy and scanning electron microscopy. Australian Journal of Soil Research, Clayton South, v. 32, n. 2, p. 285- 309, 1994.

HICKMANN, C. et al. Atributos físico-hídricos e carbono orgânico de um argissolo após 23 anos de diferentes manejos. Revista Caatinga, Mossoró, v. 25 , n. 1 , p. 128-136, 2012.

IWATA, B. DE B. et al. Sistemas agroflorestais e seus efeitos sobre os atributos químicos em 
Argissolo Vermelho-Amarelo do Cerrado piauiense. Revista Brasileira de Engenharia Agrícola e Ambiental, Campina Grande, v. 16, n. 7, p. 730$738,2012$.

LAL, R.; BRUCE, J. P. The potential of world cropland soils to sequester $\mathrm{C}$ and mitigate the greenhouse effect. Environmental Science \& Policy, New York, v. 2, n. 2, p. 177-185, 1999.

LARSON, R.; FARBER, B. Estatística Aplicada. 4th ed. Pearson Prentice Hall: São Paulo, 2010. 640 p.

MAGALHÃES, S. S. A. et al. Estoque de nutrientes sob diferentes sistemas de uso do solo de Colorado do Oeste-RO. Acta Amazônica, Manaus, v. 43, n. 1, p. 63-72, 2013.

MARTINS, E. L.; CORINGA, J. E. S.; WEBER, O. L. S. Carbono orgânico nas frações granulométricas e substâncias húmicas de um Latossolo Vermelho Amarelo distrófico - LVAd sob diferentes agrossistemas. Acta Amazônica, Manaus, v. 39, n. 3, p. 655-660, 2009.

MMA - Ministério do Meio Ambiente. Plano de Ação para prevenção e controle do desmatamento na Amazônia Legal (PPCDAm): $3^{\mathrm{a}}$ fase. (20122015) pelo uso sustentável e conservação da Floresta / Ministério do Meio Ambiente e Grupo Permanente de Trabalho Interministerial. Brasília: MMA, 2013. 174 p.

MOREIRA, A.; COSTA, D. G. Dinâmica da matéria orgânica na recuperação de clareiras da floresta amazônica. Pesquisa Agropecuária Brasileira, Brasília, v. 39, n. 10, p. 1013-1019, 2004.

RAMOS, F. T. et al. Indicadores de qualidade em um Latossolo Vermelho-Amarelo sob pastagem extensiva no pantanal matogrossense. Revista Caatinga, Mossoró, v. 23, n. 1, p. 112-120, 2010.

RAMOS, F. T. et al. Curvas de compactação de um Latossolo Vermelho-Amarelo: com e sem reuso de amostras. Engenharia Agrícola e Ambiental, Campina Grande, v. 17, n. 2, p. 129-136, 2013.

RANGEL, O. J. P.; SILVA, C. A. Estoques de carbono e nitrogênio e frações orgânicas de Latossolo submetido a diferentes sistemas de uso e manejo. Revista Brasileira de Ciência do Solo, Viçosa, v. 31, n. 6, p. 1609-1623, 2007.

RAWLS, W. J. et al. Effect of soil organic carbon on soil water retention. Geoderma, Texas, v. 116, n. 1, p. 61-76, 2003.
REDIN, M. et al. Impactos da queima sobre atributos químicos, físicos e biológicos do solo. Ciência Florestal, Santa Maria, v. 21, n. 2, p. 381-392, 2011.

ROSCOE, R.; BODDEY, R.M.; SALTON, J.C. Sistemas de Manejo e Matéria Orgânica do Solo. In: Roscoe, R. et al (Ed.). Dinâmica da Matéria Orgânica do Solo em Sistemas Conservacionistas: Modelagem matemática e Métodos Auxiliares. Dourados: Embrapa Agropecuária Oeste, 2006. p. 17 -42 .

ROSCOE, R.; BUURMAN, P. Tillage effects on soil organic in density fractions of a Cerrado Oxisol. Soil and Tillage Research, South Carolina, v. 70, n. 2, p 107-119, 2003.

ROSCOE, R.; MACHADO, P. L. O. A. Fracionamento físico do solo em estudos da matéria orgânica. Dourados, MS: Embrapa Agropecuária Oeste, 2002, 86 p.

ROSSI, C. Q. et al. Frações lábeis da matéria orgânica em sistemas de cultivo com palha de braquiária e sorgo. Ciência Agronômica, Fortaleza, v. 43, n. 1, p. 38-46, 2012.

SALTON, J. C. et al. Determinação da agregação do solo: Metodologia em uso na Embrapa Agropecuária Oeste. Dourados, MS: Embrapa Agropecuária Oeste, 2012. 8 p. (Comunicado técnico, 184).

SANTOS, H. G, et al. Sistema Brasileira de classificação do solo. 3. ed. Brasília: Embrapa Solos, 2013. 353 p.

SANTOS, A. J. et al. Viabilidade econômica do sistema agroflorestal grevílea $\mathrm{x}$ café na região norte do Paraná. Cerne, Lavras, v, 6, n. 1, p. 89-100, 2000

SILVA, C. J. et al. Contribuição de folhas na formação da serrapilheira e retorno de nutrientes em floresta de transição no norte de Mato Grosso. Acta Amazônica, Manaus, v. 39, n. 3, p. 591-600, 2009.

SILVA, I. R.; MENDONÇA, E. S. Matéria Orgânica do Solo. In: Novais, R. F. et al. Fertilidade do Solo. Viçosa, MG: Sociedade Brasileira de Ciência do Solo, p. 275-374, 2007.

STRICKLAND, M. S.; ROUSK, J. Considering fungal: bacterial dominance in soils - Methods, controls, and ecosystem implications. Soil Biology \& Biochemistry, v. 42, n. 9. p. 1385-1395, 2010.

TEDESCO, M. J. et al. Análises de solo, plantas e outros materiais. Porto Alegre, RS: Departamento de Solos, UFGRS, 1995. 174 p. 
TEIXEIRA, W. et al. Decifrando a Terra. 2. ed. São Paulo, SP: Companhia Editora Nacional, 2009. $621 \mathrm{p}$.

WHITE, R. E. Principles and Practice of Soil Science: The soil as a natural resource. 4th ed. Malden, Mass.: Blackwell, 2006, 363 p.

YEOMANS, J. C.; BREMNER, J. M. A rapid and precise method for routine determination of organic carbon in soil. Communications in Soil Science and Plant Analysis, Athens, v. 19, n. 13, p. 14671476, 1988. 